\title{
MANAS BUTHELEZI: THE CHURCH LEADER, LIBERATION ACTIVIST AND SCHOLAR IN THE SOUTH AFRICAN CONTEXT
}

\author{
James Kenokeno Mashabela \\ Christian Spirituality, Church History and Missiology \\ University of South Africa \\ jkenokeno@gmail.com
}

\section{ABSTRACT}

This article celebrates and honours Manas Buthelezi's life by examining his active contribution in the spiritual, political, social and socio-economic spheres. An analysis of his contribution is offered by firstly examining his academic career, church work and his contribution to the recent history of Christianity. Secondly, I provide an overview of his involvement in political affairs and with the Lutheran community. Finally, I focus on Buthelezi's service in the South African Council of Churches (SACC).

Keywords: Manas Buthelezi; liberation activist; apartheid; Lutheran community; South African Council of Churches (SACC)

\section{INTRODUCTION}

This article provides a historical background to the unsung hero, Manas Buthelezi. $\mathrm{He}$ actively engaged in resisting the apartheid system, was a researcher and academic, a public activist and a servant of the people. He is now a retired bishop

\section{UNISA}


and is frequently invited by various institutions to lead seminars and present papers. $\mathrm{He}$ is amongst many such heroes who contributed enormously to the liberation of South Africa. Buthelezi fought against apartheid by promoting human liberation and rights, as did other unrecognised of heroes who engaged in combating the sufferings caused by the apartheid system.

\section{THE EXPERIENCES OF MANAS BUTHELEZI IN CHURCH WORK AND ACADEMIA}

In January 1961, Buthelezi took up his first appointment in the Evangelical Lutheran Church in Southern Africa's South-Eastern Region (Zulu 2004). The congregation appointed him to serve his vicariate programme at Applesbosch Parish for a period of two months; he was then transferred to Lamontville Parish in Durban where he was later ordained as an Evangelical Lutheran pastor in November 1961 (Zulu 2004).

Buthelezi returned to South Africa in 1968 at the age of 32, having completed his doctoral degree in the United States at Drew University (Zulu 2004). Upon his return, he worked as a minister in the Ekuthuleni Parish Evangelical Lutheran Church from 1968 to 1969. The Umphumulo Theological Seminary governing board appointed Buthelezi as a lecturer where he served from January 1969 to 1970 (Umphumulo Theological College's Letter 1968). However, Buthelezi wrote a resignation letter dated 23 February 1970 to Bishop H. Fosseus of the Evangelical Lutheran Church in Southern Africa's South-Eastern Region (ELCSA-SER), giving as his reason for leaving the theological institute the fact that lecturers' salaries were unequal, based on racial discrimination (Buthelezi's letter 1970). He also requested that he be recalled for congregational work where he served from 1970-1971 as a minister in the Evangelical Lutheran congregations in Sobantu, Edendale, in Pietermaritzburg. During 1972-1973, he was transferred to minister as a parish pastor at Sobantu and Lamontville respectively. 'In 1969-71, Buthelezi served the South African Lutheran Church Committee on Church Structure as chairperson' (Deane 1978, 34). He worked in the Justice and Reconciliation committee of the South African Council of Churches (SACC) during 1972. In 1972, Buthelezi left South Africa for Germany to lecture a series in black theology at the University of Heidelberg. Buthelezi was also a gifted teacher at tertiary level, who taught theology in Germany, the United States and as a visiting lecturer in a number of European countries, including Switzerland (1963), the East, in Japan (1970) and non-European countries such as Kenya (1975) and (the then) Rhodesia (1976) (Deane 1978, 34).

On 5 March 2000 at the St. Ansgar's Central West Jabavu congregation at the Central Diocesan Centre, the Central Diocese celebrated a farewell service in honour of Bishop Dr. Manas Buthelezi and his family (Buthelezi 2000, 1), in line with the ELCSA Church tradition that celebrated the retirement of its bishops, deans and pastors. This was a concrete demonstration of God's love for the workers of the 
church by the congregants as they would bring gifts, showing appreciation for the former. Buthelezi was thanked for his contribution to the Central Diocese, ELCSA Church as a whole and his ecumenical commitment to the church of God. This included his political participation during his service to the church. His farewell sermon was on Salvation: The divine solution that lies beyond the expectations of our cries (Buthelezi 2000, 1). In this sermon, Buthelezi regarded the church's resources as the way to a practical salvation, which overcame political oppression that banned political organisations and passed harsh laws. Buthelezi said during the 1990s people were claiming, "Now we have it. Now there should be no general election anymore because we have found the perfect government that has brought final political salvation' (Buthelezi 2000, 3). Buthelezi critiqued this statement when he affirmed: 'We continually search for the right government. Democratic elections can therefore be defined as periodic searches for national salvation which lie beyond human, honest efforts' (Buthelezi 2000, 3). This indicated that South Africans would discover political, socio-economic and sociological solutions that formed part of their liberation. He said that when the church remained critical of the periodic searches for national salvation, this meant that it legitimised a search for a truly liberated South Africa. The government that South Africans needed was one that would focus on the common good in the political, economic and sociological context.

Buthelezi, in his retirement, continued to undertake the continual search for national salvation in the church as well. In 2008, Buthelezi was appointed for the period January-December 2008 by the Church Council of the Evangelical Lutheran Church in Zambia (ELCZA) to research its past, present and future under the theme Leading the ELCZA towards a realistic and sustainable direction (Buthelezi 2008, 1). This project was to diagnose the challenges and successes of ELCZA and to provide an accurate assessment of it in order to assist in the development of ELCZA, which was a small church. This project discovered that attaining a theological education remained a serious challenge to many of the pastors who were trained in Bible schools. This presented a question concerning the present and future life of that church. It was found that further academic theological education was necessary to train those pastors to make sure that they had sound theology. This was to ensure that once its pastors were trained well enough, they would be able to defend their church against anti-Christian practices. On 15 September 2008 at the Church Council meeting on mass media, Lusaka, Zambia, Buthelezi presented a report to the council, with the following proposal:

The present ELCZA is a mission church: This implies searching for a Lutheran missionary group or society which would be willing to walk and work in partnership with ELCZA, at all levels including the sharing of human and financial resources according to guidelines that can be agreed upon mutually. That ELCZA be transformed into a diocese or structural part of a neighbouring church which shall be willing to absorb into itself the existing inadequacies of ELCZA. That ELCZA 
considers negotiating a merger with one or more existing Lutheran churches in Zambia. (Buthelezi 2008, 7)

This was an imperative action that had to be taken by ELCZA if they were not to die as the small church they were, but to advance towards the future in establishing working relations with other Lutheran churches in Zambia. It was an opportunity for this body to grow and transform by networking with such churches. Members of the ELCZA network would be in a transformational dialogue with each other to reflect and decide together for a change for the better and undertake their own reflections to seek ways to be liberated and achieve a common future.

\section{BUTHELEZI IN THE RECENT HISTORY OF CHRISTIANITY IN SOUTH AFRICA}

By the late 1960s Buthelezi was already regarded as the founder of black theology in South Africa. Upon his return to South Africa in 1972 from Germany, Buthelezi continued to serve as a parish pastor. Together with Frederick Beyers Naudé of the Dutch Reformed Church (DRC) he published the progressive ecumenical bulletin which was called Pro-Veritate (For the Truth), focusing on black theology. This bulletin was critical of the government policies at the time and exposed many of the un-Christian actions of the white minority regime. Zulu describes this in the following way,

He was a Natal regional director of the Christian Institute (CI) in Pietermaritzburg from 1972-1975. In a way Buthelezi and others were prophets and advocates of thousands of voiceless South Africans. Their interrogative critical exposure of the inhuman practices brought them to a collision with the regime in South Africa. Buthelezi and other young and "hot-blooded" theologians were singing the slogan of: "Missionary go home and leave the black man (sic) ${ }^{1}$; he is matured to do his own things." At that time there was a strong focus on the independent three selves: selfsufficient, self-governing and self-propagating. (Zulu 2004, 5)

From 24-25 September 1976, the first synodical meeting of a new diocese was held at Eersterus in Pretoria, where Buthelezi was elected as the first Bishop. The Synod decided to call the new entity the Central Diocese. Buthelezi was consecrated by the then presiding bishop Paulus Ben Mhlungu of ELCSA in the Anglican St. Mary's Cathedral in Johannesburg on 12 December 1976.

Buthelezi engaged against the apartheid regime with a view to striving for South African liberation when he was the first ELCSA general secretary and bishop of the Central Diocese. Together with his Diocesan Council he created time and space for political organisations, labour unions and other organisations to use the Diocesan

1 Disclaimer: Documents which I used did not take the issue of gender equality seriously at that time; hence I use the word (sic) even concerning the gender of God: they should have been gender sensitive. I am not in favour of what the authors had written in their documents in this regard. 
centre, based in Soweto, to reflect on the liberation struggle and in order to mobilise the Church's resources to assist these entities who combated the apartheid regime. The Central Diocese did this to live out its Evangelical Lutheran doctrine of what was called the 'Two Kingdoms.' It was opposed to the government of the day with its apartheid system and supported organisations that fought against the oppression and injustices of the people of South Africa. This provided a centre to strengthen people, and provided for the birth of the black consciousness and black theology ideologies which were very critical of the apartheid regime. This remained an important time for the church to involve itself in the government's downfall through prayers and the 16 June students' uprising who critically voiced their opposition to apartheid from 1976 to 1986. It was in this context that Buthelezi was misunderstood and accused of promoting violence in the country; not he alone but with other theologians too. 'P.W. Botha has repeatedly stated that Desmond Tutu, Allen Boesak, Frank Chikane and other Christians who resist the tyranny of the state are not representative of their churches and there is indeed a yawning gap between them and what the churches have hitherto been' (ECUNEWS 1988, 19). Yet Buthelezi, Mpumulwana, Boesak, Chikane and other Christians did not ever promote violence within the country but were simply acting in opposition to the apartheid system. They tackled the government to show that God was on the side of the poor and the oppressed. For them the gospel was the truth used to reject apartheid theology. The gospel remained a legitimate authority to protect and liberate the poor and the oppressed, while apartheid theology remained illegitimate. This awakened a social conscience in the poor and the oppressed, to become advocates for and liberators of themselves.

\section{BUTHELEZI'S INVOLVEMENT IN SOCIO-POLITICAL AFFAIRS}

Buthelezi made a tremendous contribution towards the South African Students' Organization and the Black Consciousness Movement (BCM) by giving speeches (Zulu 2004). This was an era of activists such as Buthelezi, who were tested and learnt how to respond to the challenges of 16 June. It was at a time when students were resisting the imposition of the Afrikaans language on their educational system. What had been forcefully introduced by the government was regarded as a crime, in particular by the students, as well as the greater South African community. Students acted against the government, refusing to be taught in Afrikaans, which was the language of the oppressors. The effects of the Soweto uprising on 16 June have been described as follows: ' 1976 was the beginning of one of the most remarkable features of the struggle against the apartheid system: the rebellion of school children and their use of the school boycott. This required a considerable amount of organisation. The first national organisation of school students was COSAS' (Nolan 1988, 147). The government blamed Buthelezi for provoking the students to revolt against it 
(Buthelezi 2007). The actual revolt was intended to be a peaceful march, a protest against the educational system (Bantu Education) as a whole and as mentioned, in particular, Afrikaans as the medium of instruction in the schools. The Afrikaans language imposed by the regime was regarded as negative manipulation by the students of the 1970s, who wanted to create a new and redefined South African education system that drew on the principles of authentic liberation. Before the chaos of 16 June, students had already voiced their concern to the contemporary regime; their last resort was to lead to a protest which lasted for a period of 10 years that ended in 1986 (Nolan 1988, 150). This protest was periodically carried out by means of acts such as stone throwing, school boycotts and burning buildings. The protest was intended to promote human dignity and the rights of black students; the need for English as a medium of instruction; doing away with corporal punishment; and obtaining an educational equal to that of white learners. Students responded in a creative manner; 1976 was only the culmination of what had been started years earlier by Hendrik Verwoerd, at that time prime minister of South Africa:

It is the policy of my department that [black] education should have its roots entirely in the Native [black] areas and in the Native environment and Native community. There Bantu education must be able to give itself complete expression and there it will have to perform its real service. The Bantu must be guided to serve his own community in all respects. There is no place for him in the European [white] community above the level of certain forms of labour. Within his own community, however, all doors are open. For that reason it is of no avail for him to receive training which has as its aim absorption in the European community while he cannot and will not be absorbed there. Up till now he has been subjected to a school system which drew him away from his own community and partially misled him by showing him the green pastures of the European but still did not allow him to graze there. (Union of South Africa 1954)

Verwoerd's philosophical mission hindered the black people from promoting their socio-economic, political and social development and they became an underclass. This strategy was designed to exploit blacks in their own country and to effectively reap the benefits of their land ownership. The black students needed an education system that would liberate them and their citizens by gaining expertise and creatively using resources such as agriculture and minerals in South Africa.

Within a period of five days after 16 June the Black Parents' Association was established. On 21 June 1976 Buthelezi and others founded the Black Parents' Association (BPA) with the objective of establishing the whereabouts of the students who had gone missing during the upheavals of 16 June 1976 (BPA Minutes 1976). Buthelezi, as the chairperson of BPA, and his counterparts such as Winnie Mandela, Nthato Harrison Motlana and others, worked for the BPA in response to the Soweto uprising in order to dismantle apartheid and to assist the students who were its victims. In August 1976 this body passed resolutions such as demanding the 
immediate release of all detained students; and also an end to the Bantu Education system. Buthelezi attended a BPA meeting where he encouraged students to return to school. The BPA and the Christian Institute (CI) of Southern Africa were amongst the organisations allied to the BCM. On 19 October 1977, the BPA was one of the organisations banned by the government. After the banning of the BPA and some of its members, Buthelezi reported:

I was later asked by the community to pursue the matter of meeting the government because there was a deadlock in education. After a number of attempts I was able to arrange a meeting with the Deputy Minister of Police in the name of a differently constituted delegation. We discussed the matter of detained student leaders and the matter of the general behaviour of the police. We also met the Deputy Minister of Bantu Education, Mr De Beer, with whom we discussed education matters including what sparked off the 1976 students uprising. This initial opening of communication lines between the government and the Soweto community led to the creation of the Soweto Parents' Crisis Committee. (Buthelezi 2007)

The abovementioned body subsequently continued discussions with the Education Department in its own name, without Buthelezi's further direct involvement. Mr Isaac Mogase was one of the leading figures in this committee. A further development of the initial opening of communication lines with the government was the evolution of self-help efforts and self-management structures in the form of the creation of the Committee of Ten under the leadership of Buthelezi's colleague, Dr Nthato Motlana. The Committee of Ten further gave rise to the national phenomenon known as civic associations. According to Buthelezi, black theology was not to end in words but had to be seen in action, meeting the needs of those who struggled for liberation: "Nobody can deny that in our country we have many of these "least important". Among them there may be our imprisoned neighbours, banned relatives and politically detained acquaintances' (Buthelezi 1976, 6). For Buthelezi, it was vital to challenge the apartheid government: everyone who had not been banned and detained needed to be part of the movement that strove for the release of those who were. This was a living out of the ministry of presence because the gospel was proactive in reality, to create a true, new liberated society.

The committed involvement of Buthelezi in socio-political affairs was an invitation to solidarity in the struggle against the apartheid system.

Within this context, the stakes in the ideological struggle were raised. In 1977 the Lutheran World Federation (LWF), through the influence of Dr Manas Buthelezi, one of the leading South African promoters of black theology, proclaimed a status confessionis. In 1980, delegates to an SACC consultation on racism spoke of the need to establish a black confessing church, and out of this the Alliance of Black Reformed Christians (ABRECSA) emerged, drawing together the two stances on black theology and the confessing church. (De Gruchy 2006, 398) 
The stand of the confession was to declare 'apartheid sin and its theological justification a heresy'. This was likewise intended to dismantle the structures of apartheid. Buthelezi refused to accept the South African system that imposed inequality on the structures of society. For him, the gospel of liberation of the oppressed and marginalised black South Africans demanded an actual theology of liberation which opposed the sinful apartheid structures. Human rights and dignity were the constituents of an effective confession to ensure that everyone in the country benefited from the same access to privileges such as equal treatment, status and dignity. In this regard Buthelezi's contribution was vital in the effort to motivate black citizens to be their own liberators.

He needs to see his own blackness as a gift from God instead of the biological scourge which the white man's institutions have made it. Then the white man will be liberated from the urge to reject the black man because his rejection will be irrelevant and inconsequential. (Buthelezi 1973a, 56)

He also challenged whites to be liberated from their actions too. They were to make their resources and wealth equally available to the black community. This would be a gospel that was ready to bury the theology of separate development or apartheid theology, which would have been saved and resurrected by the theology of equality.

\section{LUTHERANS AND BUTHELEZI'S SERVICE IN THE SACC}

On the question of black theology, Buthelezi challenged the church to play a critical role in the liberation of black people, saying:

As a black Christian, I feel obliged to thank white Christians for having realized that God did not send them to white people only, but also to me, black as I am. In saying this, I hope that white people will also be generous enough to reciprocate this sentiment of mine as I feel moved at this hour that God has also sent me as a black person to tell them the Good News that God died in Christ to liberate the white man from his urge to oppress the black man. This means to say that the Gospel preached by the white man needs to be complemented by the Gospel through the black man. (Buthelezi 1973b, 6)

White liberated people such as Beyers Naudé, Basil Moore, Albert Nolan and others were against the apartheid system and the white people who were active in the Church but not proactive in line with the gospel. Their theology remained hypocritical to secure their wealth in order to oppress the black people. According to Buthelezi, whites were called to mobilise principled policies that would liberate themselves in order for the oppressed also to be liberated in the socio-economic and political arena. 
While the German Lutherans were under the authority of conservative missionaries, they did not play a crucial role in South African church life. However, black Lutherans were among the first to join the SACC. During the leadership of August Habelgaarn, the situation altered, when the missionary churches became autonomous and were now headed by indigenous leadership. Eight of them joined the SACC. 'They brought into the organization a powerful new voice, embodied in such figures as the Rev. August Habelgaarn and Dr Manas Buthelezi, leading exponent of black theology who served several times on the SACC executive. More individual independent churches joined during the years that followed' (Hope and Young 1981, 88). In June 1983 Buthelezi was, for the first time, elected as the president of the SACC. His co-workers at that time in the SACC were 'Archbishop Desmond Tutu (Anglican-Johannesburg) as general secretary, and more recently, Dr Beyers Naudé (former moderator of the DRC Transvaal Synod), a successor of Tutu as acting general secretary' (Bachmann and Bachmann 1989, 105). In 1986 at the National Conference of the SACC, Buthelezi delivered an opening address as the president of the SACC; his paper was titled, The radical marks of the church (Jacob 1986, 25).

For his contribution he received the following awards: Honorary membership, German Mission Society 1973; Honorary president, National Union of South African Students 1974; Doctor of Divinity, honorary degree, Susquehanna University, Pennsylvania, USA 1974; Doctor of Divinity, honorary degree, Wartburg Theological Seminary, Iowa, USA 1975; and Doctor of Theology, honorary degree, Lund University, Sweden 1976 (Deane 1978, 35). Buthelezi was and will remain an academic, prophetic and activist in the arena of South African and global economic and social justice. He was the architect of his own black theological development to the black liberation theology, one who offered a key to South Africa's controversial past and its transition to the vulnerable post-apartheid democracy.

\section{CONCLUSION}

From the above it may be observed that Buthelezi was not only a pastor in the Evangelical Lutheran Church but also an anti-apartheid activist who was deeply dissatisfied by the theology of separation. He believed that it was possible for black people to challenge whites and the apartheid regime, and that solidarity is to have respect for life and the human dignity of the black community. Buthelezi was of the view that the black liberation struggle leads to a true community within the context of reconciliation without conflict on the basis of race. He worked with others to envision the liberation of the South African community. Consequently, what we can learn from Buthelezi about black theology is that it challenges theologians to revert to what Jesus Christ is teaching: that we bring his kingdom come and his will 'on earth as it is in heaven' to deal with the current agonies of South Africa. 


\section{REFERENCES}

Black Parents' Association (BPA). 1976. Minutes of the inaugural meeting held on Monday 21 June 1976 at Methodist Youth Centre, Central Western Jabavu, Soweto, Johannesburg.

Bachmann, E.T. and Bachmann, M.B. (eds). 1989. A handbook: Lutheran churches in the world. Minneapolis: Lutheran World Federation.

Buthelezi, M. 1970. Letter to the Lutheran Umphumulo Theological College 23 February 1970. Pietermaritzburg: Lutheran Theological Institute Archive

Buthelezi, M. 1973a. Six theses: Theological problems of evangelism in the South African context. Journal of Theology for Southern Africa 3: 55-56.

Buthelezi, M. 1973b. Christianity in SA. Pro Veritate 15 June: 4-6.

Buthelezi, M 1976. The Christian Presence in Today's South Africa, Journal of Theology for Southern Africa 16, 5-8.

Buthelezi, M. 2000. Salvation: The divine solution that lies beyond the expectations of our cries. Sermon during the farewell service held in honour of Bishop M. Buthelezi and family on 5 March 2000. Johannesburg: ELCSA-Central Diocesan Archive.

Buthelezi, M. 2007.Interviewed by James Kenokeno Mashabela at Mahlabathini, Ezidwadweni on 12 October 2007. Pietermaritzburg: Lutheran Theological Institute Archive.

Buthelezi, M. 2008. Report on Evangelical Lutheran Church in Zambia extra-ordinary meeting of the Church Council, dated 15 September 2008, Mass Media, Lusaka, Zambia.

Deane, D.S. 1978. Black South Africans: A who's who 57 profiles of Natal's leading blacks. Cape Town: Oxford University Press.

De Gruchy, S. 2006. Region and racism: Struggles round segregation, 'Jim Crow' and apartheid. Unpublished.

ECUNEWS. 1988. News service of the South African Council of Churches, 14(6), June.

Hope, M. and Young, J. 1981. The South African churches in a revolutionary situation. USA: Orbis.

Jacob, S. 1986. Hope in crisis: Report of the eighteenth Annual National Conference of South African Council of Churches held at St Barnabas College, Johannesburg, 23-27 June. Johannesburg: South African Council of Churches.

Nolan, A. 1988. God in South Africa: The challenge of the gospel. Cape Town: David Philip.

Umphumulo Theological College's letter August 14, 1968. Pietermaritzburg: Lutheran Theological Institute Archive.

Union of South Africa. 1954. Senate debates, Second session, Eleventh Parliament, Fifth senate, June 7 to June 11.

Zulu, B. 2004. Interviewed by James Kenokeno Mashabela at Tembisa, ELCSA-Lesedi Congregation on 27 March 2004. Pietermaritzburg: Lutheran Theological Institute Archive. 